Bhatter College Journal of Multidisciplinary Studies | ISSN 2249-3301, Vol. VII, Number 2, 2017

Approved by the UGC \& included in Google Scholar

Article url: www.bcjms.bhattercollege.ac.in/v7/n2/v7n2eng01.pdf

Article DOI: 10.25274/bcjms.v7n2.v7n2eng01

\title{
Self, Performance and Queer militancy in Isherwood's A Single Man
}

\author{
Rajorshi Das \\ Indraprastha College for Women, Delhi
}

\begin{abstract}
Set in 1962 United States, Christopher Isherwood's A Single Man (1964), initially conceptualised as An English Woman, is considered to be the author's magnum opus. It focuses on a day in the life of the protagonist, George - a Los Angeles professor who struggles to cope up with the bereavement of his male partner and finds himself in a state of perpetual exile. While the trope of loneliness (central to many queer writings) is integral to the understanding of the protagonist's psyche, I argue that it is the Modernist "ethos of impersonality" (Gonzalez 758)' that allows us to explore the notions of minority consciousness $s^{i i}$ and gay identity politics in contemporary times.
\end{abstract}

Keywords: Christopher Isherwood, A Single Man, queer, performance, queer militancy

In a letter to Edward Upward, his life-long friend from Repton public school, Isherwood writes: "Melancholia is the occupational disease of us oldies. Senile melancholia is quite different from the romantic melancholia of the young" (Fryer 265). The very title of the novel is an indication of the protagonist's bachelorhood and suggests his sexuality. It opens with the third person detached narrator describing George's disembodied self as a "creature",iii which looks at its reflection -

Staring and staring into the mirror, it sees many faces within its face-the face of the child, the boy, the young man, the not-so-young man-all present still, preserved like fossils on superimposed layers, and, like fossils, dead. (3)

This is a Modernist embodiment of a fragmented self that lacks unity or cohesiveness and is in perpetual conflict with his surroundings. Following his migration to America, Isherwood was introduced to both Vedanta philosophy and Swami Prabhavananda by Gerald Herald who had also explained to the author that an individual has two selves - the outer self which is visible to all and the inner self that is hidden and secret (Fryer 198). I argue that this novel is meant to be the protagonist's search for this inner self which in the Upanishads would be equivalent to nothingness - the ultimate Truth. Also in Vedanta, reality is more of an illusion (Maya) and hence in order look into the inner self one has to do away with all material desires. The narrator distinguishes between the protagonist's private self and public body in a methodical manner - "Until the cortex orders it impatiently to wash, to shave, to brush its hair. Its nakedness has to be covered. It must be dressed up in clothes because it is going outside, into the world of the other people" (3). This pattern of the formation of the social self initiates the idea of performativity iv in the novel. The meticulous details of bodily movements are reiterated at the end when George's mind and body manifest a similar sense of disconnect leading to his ultimate death -

It shows no outward sign of the instant, annihilating shock. Cortex and brain stem are murdered in the blackout with the speed of an Indian strangler. Throttled out of its oxygen, the heart clenches and stops. (93)

In Christopher and His Kind (1977) Isherwood suggests that his homosexuality is a more of a rebel against his mother's majoritarian view - "She is silently brutishly willing me to get married and breed grandchildren for her. Her will is the will of Nearly Everybody and in their will is my death" (17). Isherhood's disgust at the institution of family and marriage is further explicated in his commentary on the 'Great Change' that has come over Camphor Tree Lane - 
But their wives explained to them, right from the start and in the very clearest language, that breeding and bohemianism do not mix. For breeding you need a steady job, you need a mortgage, you need credit, you need insurance. And don't you dare die, either, until the family's future is provided for. (7)

No doubt he refers the women as 'Enemy'- a coinage that can be traced back to the figure of Laily- a heavily encoded term for the conforming majoritarian adversary ${ }^{v}$ in his poems that he had composed along with Upward. In this novel, the heterosexist society is represented by the neighbours, Mr and Mrs Strunk. While the husband is downright homophobic - "tries to nail him down with a word. Queer, he doubtless growls" - the latter being "trained in the new tolerance" pities George's condition (10). This also explains why George refuses to be part of Jim's funeral - a glorified family affair - and does not tell about his partner's demise to anyone except Charlotte. In his representation of Mrs Strunk, George provides a critique of the contemporary 'pseudo-liberal sentimentally' stating in no unclear terms: "But your book is wrong... when it tells you that Jim is the substitute I found for a real son, a real kid brother, a real husband, a real wife. Jim wasn't a substitute for anything. And there is no substitute for Jim" (11). This is a complete rebuttal of the dominant state ideology represented through sacred institutions of marriage, family and all established norms of togetherness that have been increasingly celebrated in contemporary times as evident from the jubilation over the 2015 US Supreme Court judgement legalising same-sex marriages .

Following World War II, a strong anti-Communist sentiment developed in the States and in 1950 the US State Department added homosexuals in the list of people who were declared 'un-American'. Thus, a systematic effort was made to identify and trace down suspect homosexuals, humiliate them and put them in mental hospitals. George's militant gay activism (a precursor to the 1969 Stonewall riots and the Gay Liberation Movement) is a counter to this Capitalist regime of governmentality. It culminates in his political fantasies as Uncle George, a homicidal maniac, who intends to use brute force against representatives of dominant state apparatuses. His victims include the newspaper editor who campaigns against sexual minorities and the senator who supports nuclear war against Cuba thereby suggesting the association between homophobia and war-mongering ${ }^{\mathrm{vi}}$. George's Leftist militancy verges on the grotesque as he introduces dark humour to describe the fate of his victims:

"His wife may be kidnapped, garroted, embalmed and seated in the living room to await his return from the office. His children's heads may arrive in cartons by mail" (16).

While George blames the "whole (heterosexual) way of life" for Jim's death, his totalitarian construct of Uncle George makes the omniscient narrator comment - "Jim hardly matters anymore. Jim is nothing now but an excuse for hating three quarters of the population of America" (16). This authorial intervention is necessary to critique George's obsession with violence as an end in itself. Following his immigration, Isherwood came under the influence of Pacifism and despite being a Left-Wing liberal throughout his life, could not fully commit to its anti-fascist political agenda. In a letter to Stephen Spender, he writes -"I'm through with the Communists. All politicians are equally nasty. We must work for our own sort of revolution all by ourselves" (Finney 81). In fact, as early as 1930s "the organized left instead of being defenders of homosexuality increasingly saw it as a bourgeois deviation and decadence" as evident from USSR's criminalisation of the same as a "fascist perversion" in 1934 (Weeks 198).

In his constant play-acting George is fully committed to the world of maya. The question of survival in a hostile heterosexist society through a series of performances is reiterated during his lectures on Aldous Huxley's After Many Summers Dies a Swan which is a critic of US liberal thought during the Cold War. George dwells on the story of Tithonus ${ }^{\text {vii }}$ when he refers to Tennyson's poem, from where the title of Huxley's novel is derived. The purpose is not just to introduce the themes of transience, loneliness, death and decay that are integral to the protagonist's life but also use the Modernist technique of intertexuality as a means to address the subject of homosexuality in the classroom. In this context the recounting of Tithonus' agony can be seen as a critique of heterosexual love, which in the Greek legend becomes unnatural and strangulating. However, George's minority construct is not restricted to the sexual minorities alone but encompasses all oppositions to the exclusivity of any identity politics within the nation-state. Explaining the minority-majority binary he states - "a minority is only thought of as a minority when it constitutes some kind of a threat to the majority, real or imaginary" (31). The professor further deromanticizes the notion of the virtuous Other when he states -"we now run into another liberal heresy. 
Because the persecuting majority is vile, says the liberal, therefore the persecuted minority must be stainlessly pure.... A minority has its own kind of aggression. It absolutely dares the majority to attack it. It hates the majority-not without a cause, I grant you. It even hates the other minorities, because all minorities are in competition: each one proclaims that its sufferings are the worst and its wrongs are the blackest" (32). Thus, despite being a crusader of gay rights, George dispels notions of intersectionality that is integral to the Queer movement. He rather anticipates the militancy of 1990 Queer Nation Manifesto that focussed on queer rage and anger as a way to retain assert difference and occupy the margins. By reducing the sexual minority to the everyday mundane, he also rejects Edward Carpenter's glorified notions of the homosexual as an ideal species in The Intermediate Sex (1908).

Though A Single Man is not an autobiography, George's character at several levels appears to be a self-critique of the author who in Christopher and His Kind regards his pre-War writings like Lions and Shadows (1938) as being "too much fiction and too little frankness" (9) thereby suggesting a shift in his queer politics ${ }^{\text {viii }}$. George reiterates his misogynistic views of women in his description of the ailing Doris who had an affair with Jim -"I am Doris. I am Woman. I am Bitch-Mother Nature. The Church and the Law and the State exist to support me. I claim my biological rights. I demand Jim" (44). The criticism of Jim's bisexuality exposes George's own insecurity over their age difference ${ }^{\mathrm{ix}}$. He tries to overcome this realization through the celebration of his physicality - "The body that has outlived Jim and is going outlive Doris" (48). This is ironical as George is set to die in a matter of hours. At the gym, his streak of autoeroticism and narcissism is only too obvious when he looks at the reflection of his body at the mirror and muses: "Not too bad.

The bulges of flesh over the belt of the shorts are not so noticeable today. The legs are quite good. The chest muscles, when properly flexed, don't sag" (48). The gym is a democratic set-up that offers him a homoerotic space to remain youthful and sociable. Despite his earlier rejection of the notion of a minority as a perpetual victim, he now seems to contradict himself by advocating gay exclusivity.

Death is a recurrent motif in queer literature. Behind the mask of an aggressive psycho-killer, George betrays a streak of loneliness that rejects the need for privacy. Earlier in the novel, he gives a moving account of homosexual domesticity -

Think of two people, living together day after day, year after year, in this small space, standing elbow to elbow cooking at the same small stove, squeezing past each other on the narrow stairs, shaving in front of the same small bathroom mirror.... It is here that he stops short and knows, with a sick newness, almost as though it were for the first time: Jim is dead. Is dead. (4)

While George repeatedly tries to bypass his isolation by emphasizing his self-sufficiency, he cannot block away the past. He is haunted by memories of Jim while passing by the supermarket: "This bright place isn't really a sanctuary. For, ambushed among its bottles and cartons and cans, are shockingly vivid memories of meals shopped for, cooked, eaten with Jim. They stab out at George as he passes, pushing his shopping cart" (52). This also makes him visit Charlotte who had called him in the morning requesting a meeting. Unlike George - the queer diasporic subject - Charlotte is eager to return to the "masochism of old England" (68) ${ }^{x}$. The issues of Home and Exile are here further problematized by the question of sexuality. According to Anne-Marie Fortier, the Queer Home deconstructs the idea of the "familial home" as the place of comfort and belonging, thereby challenging the heteronormative world-view of the nationstate $(2)^{\mathrm{xi}}$. Therefore, for both the author and the protagonist, Home is where they assemble and establish their queer selves. For them, there can be no return to their ancestral lands which symbolise a repressive past -"the site of impossible return, the site of impossible memories" (3).

The encounter between George and Kenny provides an alternate to identity politics by focusing on the ascetic relationship between the guru and the disciple. It is through this encounter that George now becomes an "Everyman" (Wilde 128). As of them get drunk at Starboard Side bar known for its gay nightlife (and where George had met Jim for the first time), the narrator comments: "But George is drunk in a good way, and one that he seldom achieves. He tries to describe to himself what this kind of drunkenness is like. Well—to put it very crudely-it's like Plato; it's a dialogue" (74). George believes that one cannot have such kind of dialogue with a woman who only "talk in terms of the personal" as perhaps evident from his conversation with Charlotte (74). According to him a dialogue is only possible between two symbolic figures. It is based on Modernist ideal of the Impersonal that allows all secrets to be revealed without any fear of repercussions. Like George, Kenny has no nostalgic attachment to the past. 
He says - "look, I don't want to pan the past; maybe it'll mean a whole lot to me when I'm older. All I'm saying is, the past doesn't really matter to most kids my age" (75). As their conversations steer towards future, the author reiterates his scathing attack on the glorification of death as a result of war and patriotism -

Maybe the other generations before us used to think about death a lot more than we do. What I mean is, kids must have gotten mad, thinking how they'd be sent out to some corny war and killed, while their folks stayed home and acted patriotic. But it won't be like that anymore. We'd all be in this thing together. (76)

Kenny's innocent understanding (or rather ignorant) of the contemporary political scenario suggests the hope of a better future that the land of America continues to promise.

The lines between self and sexuality blur towards the end of the novel as the characters engage in a game of "paradoxical impersonal intimacy" (Gonzalez 775). As they strip naked and grapple with the dark burgeoning sea waves, George can sense a more symbolic stripping of all his anxieties and bodily desires. He now has an exclusive access to the infinite that is not visible to the rest. As Kenny remarks: "We are invisible- don't you know?" (80). It is a spiritual purification of the carnal body that is now ready to break the cycle of the Karma: "Giving himself to it utterly, he washes away thought, speech, mood, desire, whole selves, entire lifetimes; again and again he returns, becoming always cleaner, freer..." (80). As George and Kenny go to the former's place, the conversation no longer remains impersonal, steering towards Jenny's girlfriend Lois who too is a minority immigrant from Japan and is extremely conscious of her status as an outsider. George believes that he is aware of Kenny's real purpose and suggests his inability to give that knowledge of Eros to him. As he falls asleep and momentarily wakes up to find Kenny's letter, he experiences a strong desire to masturbate and manages to do so only when he envisions the boy making out with the male tennis player (whom he had seen in the university campus). Isherwood once gain invokes the Hindu concept of the Maya (which suggests that reality is nothing but an illusion) when he says: "But is all of George altogether present here?" (91). Like the formation of his social self at the beginning of the novel, George's death is methodical and climactic. Commenting on its ending, Anthony Burgess writes: "After the metaphorical death of the orgasm" and "the sham death of sleep comes the true but hypothetical death of the body"xii (256). I argue that the death of George's corporeal body is his only means to transcendence. In The Space Within The Heart (1970) Aubrey Menen, a fellow anti-imperialist gay author mentions that discovering the inner self is like peeling an onion: "One by one, you strip away those parts of your personality which consist of the things that you do because the world taught you to do them" until one finds the true self- "the Tranquil Eye" $(8,9)$. Since this Ultimate Truth is equivalent to nothingness, George's dead body is now mere garbage ready to be "carted away and disposed of" (93). Thus it only through death that the protagonist can obliterate the consciousness of past and the memories of Jim. His soul triumphs over body as the former continues to live on.

A Single Man is neither completely a treatise of gay propaganda nor an affirmation of spirituality over sexuality. It is rather a critique of the human condition in era of Cold War and emphasizes the need to recognise the illusory nature of self. By using the term Queer as an all-encompassing minority identity, Isherwood also registers a protest against the state politics of the time.

\section{Notes}

\footnotetext{
' Gonzalez (2013) in fact argues that the novel is a celebration of identity politics as a primary "weapon of literarycultural gay activism" (758).

ii Claude Summers (2007) identifies this as the central concern of the novel

iii Homosexuality has often been associated with not just anti-imperialism but also vegetarianism and animal rights. Edward Carpenter, for example has been a leading advocate of animal rights. The identification of the queer self with a non-human Other (in this case, a "creature") is also central to the works of Indian writers like Vikram Seth and Suniti Namjoshi.

iv Judith Butler would later describe Performativity as an effect of reiterated acting in Gender Trouble (1999)

v This is similar to W.H. Auden's reference to the "supreme Antagonist" in his poem 'Consider'. As in Isherwood's case, the meanings of these coinages have evolved with time and are not constant.
} 
${ }^{\mathrm{vi}}$ The novel is set in the aftermath of Cuban missile crisis- a thirteen-day confrontation between US and Soviet Union over the deployment of ballistic missiles in Cuba, which in turn was a result of Fidel Castro seeking protection from the Soviets after successfully resisting US forces in 1961.

vii In Greek mythology Tithonus was a lover of Eos who had asked Zeus to make him immortal but forgot to request for his eternal youth. Tithonus is said to have eventually turned into a cicada, eternally begging for death.

viii There are various examples of self-censorships in nineteenth century literature. While E M Forster's Maurice was not published until 1971, Virginia Woolf's Orlando (1928) was written in a fantasy mode and managed to avoid the fate of Radclyffe Hall's The Well of Loneliness (1928) which was steeped in realism.

ix The character of Jim is believed to have been based on Isherwood's partner Don Bachardy who was younger to him by almost thirty years.

${ }^{x}$ Isherwood here toys with his own reasons for not returning to England whom he had equated with heterosexual dictatorship.

xi This explains Isherwood's anti-War propaganda and his refusal to fight for England during World War II

xii Cited by Finney (1979)

\section{Bibliography}

Carpenter, Edward. The Intermediate Sex. 1908. London: Forgotten Books, 2013. Print.

Finney, Brian. Christopher Isherwood: A Critical Biography. New Delhi: OUP, 1979. Print.

Fortier, Anne-Marie. 'Queer Diaspora' Handbook of Lesbian and Gay Studies. Eds. Diane Richardson and Steven Seidman. Thousand Oaks, CA: SAGE, 2002. Print.

Fryer, Jonathan. Isherwood: A Biography of Christopher Isherwood. London: New English Library, 1977. Print.

Gonzalez, Octavio R. "Isherwood's Impersonality: Ascetic Self-Divestiture and Queer Relationality in A Single Man” MFS Modern Fiction Studies 59.4 (2013): 758-783. PROJECT MUSE. Web. 10 Apr. 2015

Isherwood, Christopher. A Single Man. 1964. Minneapolis: U of Minnesota P, 2001. Print.

Isherwood, Christopher. Christopher and His Kind. London: Eyre Methuen, 1977. Print.

Menen, Aubrey. 1970. The Space Within The Heart: An Autobiography. New Delhi: Penguin Books, 1991. Print.

Summers, Claude. Foreword. Isherwood on Writing. Ed. James J. Berg. Minneapolis: U of Minnesota Press, 2007. vii-xv.

Weeks, Jeffrey. 1977. Coming Out. London, New York: Quarlet Books, 1990. Print.

Wilde, Alan. Christopher Isherwood. New York: Twayne Publishers, 1971. Print.

Rajorshi Das is a queer research scholar and poet who is currently occupied with the possibilities and limitations of intersectionality in South Asia. He teaches at Indraprastha College for Women, Delhi as an assistant professor (ad-hoc) in English. 